\title{
Oligoether/Zwitterion Diblock Copolymers: Synthesis and Application as Cathode-Coating Material for Li Batteries
}

\author{
Masahiro Yoshizawa-Fujita *(D), Jun Ishii, Yuko Takeoka (D) and Masahiro Rikukawa (D) \\ Department of Materials and Life Sciences, Sophia University, 7-1 Kioi-cho, Chiyoda-ku, Tokyo 102-8554, Japan; \\ jun-ishii@nisshinbo.co.jp (J.I.); y-tabuch@sophia.ac.jp (Y.T.); m-rikuka@sophia.ac.jp (M.R.) \\ * Correspondence: masahi-f@sophia.ac.jp
}

Citation: Yoshizawa-Fujita, M.; Ishii,

J.; Takeoka, Y.; Rikukawa, M.

Oligoether/Zwitterion Diblock

Copolymers: Synthesis and Application as Cathode-Coating Material for Li Batteries. Polymers 2021, 13, 800. https://doi.org/ $10.3390 /$ polym 13050800

Academic Editor: Antonino S. Aricò

Received: 19 February 2021

Accepted: 2 March 2021

Published: 5 March 2021

Publisher's Note: MDPI stays neutral with regard to jurisdictional claims in published maps and institutional affiliations.

Copyright: (c) 2021 by the authors. Licensee MDPI, Basel, Switzerland. This article is an open access article distributed under the terms and conditions of the Creative Commons Attribution (CC BY) license (https:// creativecommons.org/licenses/by/ $4.0 /)$.

\begin{abstract}
Poly (ethylene oxide) (PEO) has been investigated as an ion-conductive matrix for several decades due to its excellent properties. However, further improvements are needed to enable a PEObased ion-conductive matrix for practical applications. In order to develop novel solid polymer electrolytes based on zwitterions, we synthesized diblock copolymers (PPEGMA-b-SPBs) with oligoether and zwitterionic side-chains and evaluated their physico-chemical properties. PPEGMA- $b$-SPBs with various unit ratios were synthesized by RAFT polymerization. PPEGMA-b-SPBs with/without LiTFSA exhibited two distinct glass transition temperatures regardless of the unit ratio of PEGMA and SPB. AFM observations clearly revealed phase-separated structures. The ionic conductivity of PPEGMA- $b$-SPBs increased even at a high salt concentrations such as [EO]:[Li] $=6: 1$ and was over $10^{-5} \mathrm{~S} \mathrm{~cm}^{-1}$ at $25^{\circ} \mathrm{C}$. This tendency is unusual in a PEO matrix. The oxidation stability of PPEGMA$b$-SPBs was about $5.0 \mathrm{~V}$ vs. $\mathrm{Li} / \mathrm{Li}^{+}$, which is a higher value than that of PEO. The improvement of the electrochemical properties is attributed to the introduction of the SPB block into the block copolymers. PPEGMA- $b$-SPBs were evaluated as cathode-coating materials for Li batteries. The discharge capacity and coulombic efficiency of the cells employing the cathode $\left(\mathrm{LiNi}_{1 / 3} \mathrm{Mn}_{1 / 3} \mathrm{Co}_{1 / 3} \mathrm{O}_{2}(\mathrm{NMC})\right.$ ) coated with the block copolymers were much higher than those of the cell employing the pristine cathode at the 50th cycle in the cut-off voltage range of 3.0-4.6 V.
\end{abstract}

Keywords: solid polymer electrolytes; zwitterions; RAFT polymerization; cathode; Li batteries

\section{Introduction}

Poly (ethylene oxide) (PEO) has been investigated as an ion-conductive matrix for several decades due to its excellent properties, such as high polarity to dissociate Li-salts and flexibility to transport Li-ions along the polymer chain [1,2]. The ionic conductivity of PEO-based electrolytes is about $10^{-4} \mathrm{~S} \mathrm{~cm}^{-1}$ at room temperature. PEO can be utilized as a solid electrolyte for rechargeable batteries, e.g., Li-ion batteries. However, further improvements are needed to enable a PEO-based ion-conductive matrix for practical applications. Although an abundance of PEO derivatives have been reported, it is difficult to improve the ionic conductivity of PEO-based electrolytes. This is because the glass transition temperature $\left(T_{\mathrm{g}}\right)$ increases and the ionic conductivity decreases as the concentration of Li-salt increases. In other words, there is a trade-off relationship between Li-ion concentration and Li-ion mobility. On the other hand, polycarbonate-based electrolytes have been reported as alternative solid polymer electrolytes [3-5]. Their ionic conductivity is about $10^{-7}$ to $10^{-3} \mathrm{~S} \mathrm{~cm}^{-1}$ at $60^{\circ} \mathrm{C}$, and the lithium transport number $\left(t_{\mathrm{Li}+}\right)$ is typically in the range 0.4 to 0.8 . Polycarbonate-based electrolytes are fascinating materials as an alternative to PEO, but the oxidation potential is around $3 \mathrm{~V} \mathrm{[4],} \mathrm{which} \mathrm{is} \mathrm{lower} \mathrm{than} \mathrm{that}$ of PEO-based electrolytes.

Additives are being actively studied in order to easily improve various properties of PEO. The ionic conductivity and $t_{\mathrm{Li}+}$ of PEO-based electrolytes and resistance at the electrolyte/electrode interface are improved by adding plasticizers [6,7] and inorganic 
fillers [8,9] to PEO-based electrolytes. On the other hand, zwitterions [10-12], which have both a cation and anion in the same molecule, have been proposed as new additives. The ionic conductivity and diffusion coefficient of Li-ion in polymer gel electrolytes are improved by the addition of zwitterions [13,14]. Furthermore, such improvements are also observed when zwitterions are added to ionic liquids, and the coulombic efficiency based on the electrochemical redox reaction of $\mathrm{Li}$ is improved [15].

The melting points of typical zwitterions are above $100{ }^{\circ} \mathrm{C}$, hence zwitterions are solid at room temperature [11]. Recently, we succeeded in synthesizing zwitterions that are liquid at room temperature [16]. Furthermore, we found that liquid zwitterions improve the electrochemical (oxidation) stability of oligoether compounds [17,18]. Generally, the oxidation potential of PEO-based electrolytes is about $4.0 \mathrm{~V} \mathrm{vs.} \mathrm{Li} / \mathrm{Li}^{+}[19,20]$, and cathode active materials such as $\mathrm{LiCoO}_{2}(\mathrm{LCO})$ and $\mathrm{LiNi}_{1 / 3} \mathrm{Mn}_{1 / 3} \mathrm{Co}_{1 / 3} \mathrm{O}_{2}$ (NMC) cannot be applied as high potential electrodes in Li-ion batteries with PEO-based electrolytes. Interestingly, when a small amount of zwitterion was added to oligoethers, the oxidation potential of oligoethers was improved to about $5 \mathrm{~V}$. The combination of zwitterion and oligoether is interesting as an electrolyte material. However, oligoether electrolytes are liquids and have the same problems such as liquid leakage and volatility as organic electrolyte solutions. By developing polymer electrolyte membranes, not only can the above problems be solved, but also separator-free batteries can be fabricated. These allow us to develop safe and flexible devices. In order to develop novel solid polymer electrolytes based on zwitterions and oligoethers, we synthesized random copolymers with zwitterionic and oligoether side-chains [21]. Their lithium bis(trifluoromethanesulfonyl)amide (LiTFSA) composites exhibited an ionic conductivity of $10^{-4} \mathrm{~S} \mathrm{~cm}^{-1}$ at $80^{\circ} \mathrm{C}$. Contrary to conventional PEO-based electrolytes, their ionic conductivity was maintained even at high LiTFSA concentration because the high dipole moment of zwitterions leads to a dissociation of LiTFSA through electrostatic interaction [22,23].

There is a great interest in the use of microphase-separated block copolymers as solid electrolytes in rechargeable batteries [24]. Poly(styrene- $b$-oligoether)s have been proposed to satisfy both high ionic conductivity and excellent mechanical properties $[25,26]$. Poly(styrene- $b$-zwitterion)s have been reported as solid polymer electrolytes [27]. To the best of our knowledge, solid polymer electrolytes based on the block copolymers composed of zwitterionic and oligoether side-chains have not been reported. In this report, diblock copolymers with zwitterionic and oligoether side-chains are synthesized by reversible addition-fragmentation chain transfer (RAFT) polymerization. The thermal and electrochemical properties of the diblock copolymers are evaluated. The influence of unit ratio and Li-salt concentration on physico-chemical properties are investigated. Furthermore, Li batteries are fabricated to evaluate the diblock copolymers as cathodecoating materials because the oxidation stability of the diblock copolymers is improved to about $5 \mathrm{~V}$, as with the oligoether electrolytes containing zwitterions (vide supra).

\section{Materials and Methods}

\subsection{Materials}

1,4-Dioxane (99.5\%), hexane (96.0\%), ethyl acetate (99.5\%), and acetone $(99.5 \%)$ were purchased from FUJIFILM Wako Pure Chemical Corp. (Chuo-ku, Osaka, Japan). The 1,1,1,3,3,3-Hexafluoro-2-propanol (HFIP) $(99.0 \%)$ was purchased from Tokyo Chemical Industry Co., Ltd. (Chuo-ku, Tokyo, Japan). Poly (ethylene glycol) methyl ether methacrylate (PEGMA) (Sigma-Aldrich (St. Louis, MO, USA), 100 ppm MEHQ as inhibitor, 200 ppm BHT as inhibitor) was purified by alumina column (Merck KGaA, Ltd. (Darmstadt, Germany)) in order to remove inhibitor before use. [2-(Methacryloyloxy]ethyl)dimethyl-(3sulfopropyl)ammonium hydroxide (SPB) (Sigma-Aldrich (St. Louis, MO, USA), 95\%) was recrystallized in the mixed solvent (acetone:methanol $=10: 1$ ) before use. 4-Cyano-4(phenylcarbonothioylthio)pentanoic acid (CTPA) (Sigma-Aldrich (St. Louis, MO, USA), $97.0 \%$ ) was recrystallized in the mixed solvent (hexane:ethyl acetate $=2: 3$ ) before use. 2,2'-Azobis(isobutyronitrile) (AIBN) (FUJIFILM Wako Pure Chemical Corp. (Chuo-ku, 
Osaka, Japan)) and 4,4'-azobis(4-cyanovaleric acid) (ACVA) (FUJIFILM Wako Pure ChemicalCorp. (Chuo-ku, Osaka, Japan)) were recrystallized from methanol before use. N-Methyl$\mathrm{N}$-propylpyrrolidinium bis(fluorosulfonyl) amide ([P13][FSA]) was synthesized according to the procedure published in the literature [28]. Lithium bis(trifluoromethylsulfonyl)amide (LiTFSA) (Kanto Chemical Co., Inc. (Chuo-ku, Tokyo, Japan), 99.7\%) and lithium bis(fluorosulfonyl) amide (LiFSA) (Kishida Chemical Co., Ltd. (Chuo-ku, Osaka, Japan), 99.0\%) were dried at $100{ }^{\circ} \mathrm{C}$ in vacuo before use. Lithium foils (thickness: $0.4 \mathrm{~mm}$, diameter: $16 \mathrm{~mm}$ ) were purchased from Honjo Metal Co., Ltd. (Osaka, Japan). Poly(vinylidene difluoride) (PVDF) (\#1120) was purchased from Kureha Battery Materials Japan Co., Ltd. (Chuo-ku, Tokyo, Japan). Acetylene black (AB) was purchased from Denka Ltd. (Chuo-ku, Tokyo, Japan). $\mathrm{LiNi}_{1 / 3} \mathrm{Mn}_{1 / 3} \mathrm{Co}_{1 / 3} \mathrm{O}_{2}$ (NMC) (average particle diameter: $0.81 \mu \mathrm{m}$ ) was purchased from Kusaka Rare Metal Products Co., Ltd. (Minato-ku, Tokyo, Japan).

\subsection{Synthesis of PPEGMA}

PEGMA (10.0 g, $\left.2.00 \times 10^{-2} \mathrm{~mol}\right)$, CTPA $\left(39.2 \mathrm{mg}, 1.40 \times 10^{-4} \mathrm{~mol}\right)$, and AIBN $(4.9 \mathrm{mg}$, $\left.3.0 \times 10^{-5} \mathrm{~mol}\right)$ were dissolved in 1,4-dioxane $(30 \mathrm{~mL})$ and placed in dried polymerization tubes. The polymerization mixtures were degassed with five pump thaw cycles, and then the tubes were sealed under nitrogen. The polymerization tubes were placed into a shaker at $70^{\circ} \mathrm{C}$. After $15 \mathrm{~h}$, the reaction systems were cooled down in an ice bath. The polymer was purified by dialysis against pure water $\left(18.1 \mathrm{M} \Omega \mathrm{cm}^{-1}\right)$ and recovered by freeze drying, yielding polymers (PPEGMA) as pink oils (yield: $91 \%) . M_{n}$ (DMF, PEO/PEG standards) $=$ $33,000 \mathrm{~g} \mathrm{~mol}^{-1}, M_{\mathrm{w}}$ (DMF, PEO/PEG standards) $=35,300 \mathrm{~g} \mathrm{~mol}^{-1}, M_{\mathrm{W}} / M_{\mathrm{n}}=1.07$. The polymerization degree $(n)$ of PPEGMA $n$ was determined to be $68 .{ }^{1} \mathrm{H}$ NMR spectroscopy $\left(\mathrm{D}_{2} \mathrm{O}\right)$ : 4.47-4.14 (3.98H, s), 4.02-3.53 (33.08H, m), 3.38-3.30 (3.04H, s), 2.34-1.71 $(2.00 \mathrm{H}, \mathrm{m})$, $1.43-0.83(12.96 \mathrm{H}, \mathrm{d})$. Analytical calculations for $\mathrm{C}_{1496} \mathrm{H}_{2856} \mathrm{O}_{750} \mathrm{~N}_{1} \mathrm{~S}_{2}(\%)$ : C, 54.77; H, 8.74; N, 0.04; S, 0.19; Found (\%): C, 54.99; H, 9.04; N, 0.03; S, 0.04 .

\subsection{Synthesis of PPEGMA-b-SPB}

The chain extension of PPEGMA 68 to PPEGMA ${ }_{68}-b-\mathrm{SPB}_{m}$ was carried out in a similar manner as RAFT polymerization of PPEGMA 68 . These copolymers were referred to as PPEGMA $_{68}-b-\mathrm{SPB}_{m}$, where 68 and $m$ represent the number of PEGMA and SPB units in the copolymers, respectively. SPB, PPEGMA $68\left(2.00 \mathrm{~g}, 6.06 \times 10^{-5} \mathrm{~mol}\right)$ and ACVA $(1.4 \mathrm{mg}$, $\left.5.0 \times 10^{-6} \mathrm{~mol}\right)$ were dissolved in pure water $\left(18.1 \mathrm{M} \Omega \mathrm{cm}^{-1}\right) 25 \mathrm{~mL}$ and placed in dried polymerization tubes. The polymerization mixture was degassed with five pump thaw cycles, and then the tubes were sealed under nitrogen. The polymerization tubes were placed into a shaker at $70{ }^{\circ} \mathrm{C}$. After $15 \mathrm{~h}$, the reaction systems were cooled down in an ice bath. The polymer was purified by dialysis against pure water $\left(18.1 \mathrm{M} \Omega \mathrm{cm}^{-1}\right)$ and recovered by freeze drying, yielding polymers as pink solids (general yields: $70-80 \%$ ).

${ }^{1} \mathrm{H}$ NMR spectroscopy $\left(\mathrm{D}_{2} \mathrm{O}\right): 4.62-4.28(0.51 \mathrm{H}, \mathrm{s}), 4.23-4.06(0.52 \mathrm{H}, \mathrm{s}), 3.89-3.61$ $(12.01 \mathrm{H}, \mathrm{m}), 3.60-3.50(1.15 \mathrm{H}, \mathrm{m}), 3.49-3.29(1.03 \mathrm{H}, \mathrm{s}), 3.28-3.09(3.02 \mathrm{H}, \mathrm{s}), 3.01-2.87(1.00 \mathrm{H}$, s), 2.36-2.10 $(1.00 \mathrm{H}, \mathrm{s}), 2.09-1.68(1.43 \mathrm{H}, \mathrm{m}), 3.49-3.29(2.22 \mathrm{H}, \mathrm{m}) . M_{\mathrm{n}}\left({ }^{1} \mathrm{H}\right.$ NMR, $\left.\mathrm{D}_{2} \mathrm{O}\right)=$ $67,000 \mathrm{~g} \mathrm{~mol}^{-1}$. Analytical calculations for $\mathrm{C}_{1496} \mathrm{H}_{2856} \mathrm{O}_{750} \mathrm{~N}_{1} \mathrm{~S}_{2}(\%)$ : $\mathrm{C}, 50.99 ; \mathrm{H}, 8.15 ; \mathrm{N}$, $2.55 ; \mathrm{S}, 5.90$; Found (\%): C, 48.41; H, 8.28; N, 2.42; S, 5.76.

\subsection{Preparation of Neat and Li Composite Films}

In an Ar filled globe box, given amounts of PPEGMA ${ }_{68}-b-\mathrm{SPB}_{m}$ and LiTFSA were dissolved in HFIP, and these mixtures were stirred at $25^{\circ} \mathrm{C}$ for $24 \mathrm{~h}$. Then, these solutions were cast on a PTFE plate and were dried at $25^{\circ} \mathrm{C}$ for $24 \mathrm{~h}$ and $60^{\circ} \mathrm{C}$ for $48 \mathrm{~h}$ under a nitrogen atmosphere. These films were dried in vacuo at $60^{\circ} \mathrm{C}$ for $48 \mathrm{~h}$ before use. The LiTFSA concentration was varied from $[\mathrm{EO}] /[\mathrm{Li}]=6: 1$ to $24: 1$.

\subsection{Methods}

${ }^{1} \mathrm{H}$ NMR measurements were carried out on a Bruker Avance III HD Nanobay 400 NMR spectrometer to confirm the chemical structures of products. Elemental analyses 
were carried out with a GC elemental analyzer (PE 2400-II, PerkinElmer, Inc. (Waltham, MA, USA)). The molecular weight and molar mass dispersity of PPEGMA 68 were determined with gel permeation chromatography (GPC, PEO/PEG standard, Tosoh Corp. (Yamaguchi, Japan)) using DMF solution with $0.1 \mathrm{wt} \% \mathrm{LiCl}$ as the eluent $\left(1.0 \mathrm{~mL} \mathrm{~min}{ }^{-1}\right)$ at $40{ }^{\circ} \mathrm{C}$.

The thermal properties were measured by thermogravimetric analysis (TGA; TGDTA7200, Hitachi High-Tech Corp. (Minato-ku, Tokyo, Japan)). The samples were heated from $25{ }^{\circ} \mathrm{C}$ to $500{ }^{\circ} \mathrm{C}$ at a scan rate of $10^{\circ} \mathrm{C} \mathrm{min}-1$ under a nitrogen atmosphere. The thermal behavior of the samples was measured with differential scanning calorimetry (DSC) (DSC7020, Hitachi High-Technologies Corp.) between -150 and $150{ }^{\circ} \mathrm{C}$ at a heating/cooling rate of $10^{\circ} \mathrm{C} \mathrm{min}^{-1}$.

The morphology of the film surface was measured by atomic force microscopy (AFM; SPM-9600, Shimadzu Corp. (Kyoto, Japan)). The AFM images were generated in the tapping mode with an amplitude ratio within $0.90-1.00$ to avoid monolayer damage. The AFM cantilevers (NCHR-20, Nanoworld Co., Ltd. (Switzerland)) had spring constants in the range of $42 \mathrm{~N} \mathrm{~m}^{-1}$, the scanning range was $1 \mu \mathrm{m} \times 1 \mu \mathrm{m}$ and the scanning rate was $1.0 \mathrm{~Hz}$.

The ionic conductivity values of the samples were obtained by measuring the complex impedance between $100 \mathrm{mHz}$ and $1 \mathrm{MHz}$ (applied voltage: $10 \mathrm{mV}$ ) using an impedance analyzer (VSP-300, BioLogic (France) ) over the temperature range of -40 to $100^{\circ} \mathrm{C}$. The temperature was controlled using a constant-temperature oven (SU-262, Espec Corp. Kitaku, Osaka, Japan). A stainless steel cell (TYS-00DM01, Toyo System Co., Ltd. (Fukushima, Japan)) was used. Two platinum plates polished with 1.0, 0.3, and $0.05 \mu \mathrm{m} \mathrm{Al}_{2} \mathrm{O}_{3}$ powder were used as the electrode. The AC impedance method was used to analyze the ionic conductivity of the block copolymers at various temperatures. The ionic conductivity of the electrolytes was determined using

$$
\sigma=\frac{d}{R S}
$$

where $\sigma$ represents ionic conductivity, $R$ is the intercept at the real axis in the impedance Nyquist plot, $S$ is the geometric area of the electrolyte-electrode interface, and $d$ is the distance between the two electrodes.

Cyclic voltammetry measurements (CV; VSP-300, BioLogic (France)) were carried out in the potential range of -0.25 and $1.0 \mathrm{~V}$ at $60^{\circ} \mathrm{C}$ at a scan rate of $1.0 \mathrm{mV} \mathrm{s}^{-1}$ with lithium foils as the reference and counter electrodes. A stainless steel cell (TYS-00DM01, Toyo System Co., Ltd. (Fukushima, Japan)) was used as the CV measurement cell. A nickel plate polished with 1.0, 0.3 , and $0.05 \mu \mathrm{m} \mathrm{Al}_{2} \mathrm{O}_{3}$ powder was used as the working electrode. Linear sweep voltammetry (LSV) measurements (VSP-300, BioLogic (France)) were carried out in the potential range of 3.0 to $6.0 \mathrm{~V}$ at $60^{\circ} \mathrm{C}$ at a scan rate of $1.0 \mathrm{mV} \mathrm{s}^{-1}$. Lithium foils were used as the reference and counter electrodes, while platinum plates were used as working electrodes in the potential ranges of 3.0 to $6.0 \mathrm{~V}$.

NMC ( $85 \mathrm{wt} \%), \mathrm{AB}(6 \mathrm{wt} \%)$, and PVDF (9 $\mathrm{wt} \%)$ were mixed in $\mathrm{N}$-methylpyrrolidone, then the composite solution was cast on the current collector, aluminum foil. The coated aluminum foils were dried at $80^{\circ} \mathrm{C}$ for $1 \mathrm{~h}$ and were pressed at $6 \mathrm{MPa}$ and $70^{\circ} \mathrm{C}$ for $1 \mathrm{~h}$. The coated aluminum foils were used as the pristine cathode. For application to cathode-coating material, PPEGMA $68_{6}-b-\mathrm{SPB}_{121}$ was applied onto the cathode. PPEGMA $68^{-b}-\mathrm{SPB}_{121} / \mathrm{HFIP}$ solution $\left(10 \mathrm{mg} \mathrm{mL}^{-1}\right.$ ) was prepared. Spin coating (1H-D7, Mikasa (Minato-ku, Tokyo, Japan) was used for the fabrication of thin films to deposit a uniform coating of the block copolymer on the cathode surface and was performed at $3000 \mathrm{rpm}$ for $30 \mathrm{~s}$. The coated cathodes were dried at $60^{\circ} \mathrm{C}$ for $48 \mathrm{~h}$. Lithium foils were used as the anode. $\left[\mathrm{C}_{3}\right.$ pyr] [FSA]/LiFSA $\left(0.32 \mathrm{~mol} \mathrm{~kg}^{-1}\right)$ was used as the electrolyte for charge/discharge tests. Charge/discharge tests were carried out using a battery charge/discharge system (HJ-SD8, Hokuto Denko Corp. (Meguro-ku, Tokyo, Japan)). The cathode, anode, and separator (GA-55, Advantec (Chiyoda-ku, Tokyo, Japan)) soaked with the electrolyte were 
assembled in a stainless steel cell (TYS-00DM01, Toyo System Co., Ltd.) in an Ar-filled glove box $\left(\mathrm{H}_{2} \mathrm{O}<1 \mathrm{ppm}, \mathrm{O}_{2}<1 \mathrm{ppm}\right)$ to minimize moisture contamination.

\section{Results and Discussion}

\subsection{Synthesis of Oligoetehr/Zwitterion Diblock Copolymers}

A homopolymer of PEGMA, PPEGMA was synthesized by RAFT polymerization in 1,4-dioxane. The number-average molar mass $\left(\mathrm{M}_{\mathrm{n}}\right)$ and mass-average molar mass $\left(M_{\mathrm{w}}\right)$ were determined by GPC measurements to be 33,000 and $35,300 \mathrm{~g} \mathrm{~mol}^{-1}$, respectively. The molar mass dispersity $\left(\bigoplus_{M}\right)$ was calculated from the molecular weight values to be 1.07, indicating that the molecular weight of PPEGMA is well-controlled by RAFT

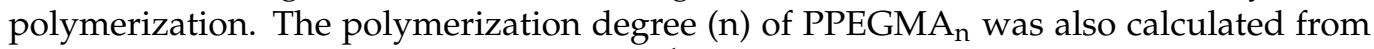
the $\mathrm{M}_{n}$ value to be 68 . Figure 1a shows the ${ }^{1} \mathrm{H}$ NMR spectrum of PPEGMA ${ }_{68}$ in $\mathrm{D}_{2} \mathrm{O}$. The chemical shifts of the methacrylate group were observed at about 1.0 and $2.0 \mathrm{ppm}$. The chemical shifts, which are assigned to the oligoether side-chain of PEGMA, were observed in the range of 3.0 to $4.0 \mathrm{ppm}$. These results confirm the successful synthesis of PPEGMA.

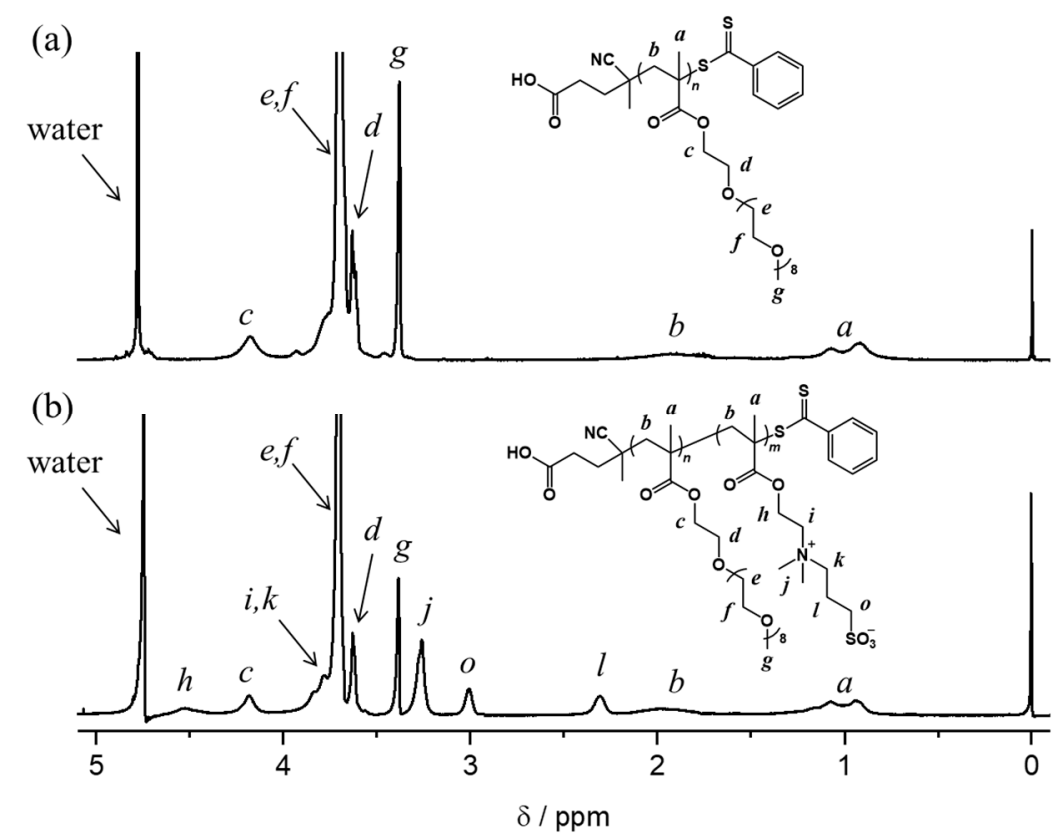

Figure 1. ${ }^{1} \mathrm{H}$ NMR spectra of (a) PPEGMA 68 and (b) PPEGMA 68 -b-SPB 121 in $\mathrm{D}_{2} \mathrm{O}$.

We synthesized four kinds of diblock copolymers, $\mathrm{PPEGMA}_{68}-b-\mathrm{SPB}_{\mathrm{m}}$, with various SPB unit numbers as summarized in Table 1 . The number-averaged molar mass $\left(\mathrm{M}_{\mathrm{n}}\right)$ of PPEGMA $_{68}-b-\mathrm{SPB}_{\mathrm{m}}$ was determined by ${ }^{1} \mathrm{H}$ NMR measurements to be in the range of 37,800 and $67,000 \mathrm{~g} \mathrm{~mol}^{-1}$. Figure $1 \mathrm{~b}$ shows the ${ }^{1} \mathrm{H}$ NMR spectrum of PPEGMA $68^{-}-b-\mathrm{SPB}_{121}$ in $\mathrm{D}_{2} \mathrm{O}$. The chemical shifts of the zwitterionic side-chain were observed in the range of 2.2 to $4.0 \mathrm{ppm}$. From these results, the block copolymers composed of PEGMA and SPB were successfully obtained by RAFT polymerization. The SPB unit numbers $(\mathrm{m})$ were calculated from the $M_{n}$ values of diblock copolymers and were in the range of 17 and 121 . The ratio of $\mathrm{m}$ and $\mathrm{n}(\mathrm{m} / \mathrm{n})$ was determined to be from 0.25 to 1.8 . 
Table 1. Molecular Weights $\left(M_{n}\right)$ and Glass Transition Temperatures $\left(T_{\mathrm{g}}\right)$ of PPEGMA $_{68}-b-\mathrm{SPB}_{\mathrm{m}}$.

\begin{tabular}{|c|c|c|c|c|c|}
\hline Sample & $M_{\mathrm{n}}{ }^{a} / \mathrm{g} \mathrm{mol}^{-1}$ & $m^{b}$ & $m / n^{c}$ & $T_{\mathrm{g}, \mathrm{L}} d /{ }^{\circ} \mathrm{C}$ & $T_{\mathrm{g}, \mathrm{H}}{ }^{e}{ }^{\circ} \mathrm{C}$ \\
\hline PPEGMA $_{68}-b-\mathrm{SPB}_{121}$ & 67,000 & 121 & 1.8 & -78 & 10 \\
\hline PPEGMA $_{68}-b-\mathrm{SPB}_{62}$ & 50,500 & 62 & 0.91 & -76 & 2 \\
\hline PPEGMA $_{68}-b-\mathrm{SPB}_{31}$ & 42,000 & 31 & 0.46 & -70 & 7 \\
\hline PPEGMA $_{68}-b-\mathrm{SPB}_{17}$ & 37,800 & 17 & 0.25 & -70 & 6 \\
\hline
\end{tabular}

${ }^{a}$ Determined by ${ }^{1} \mathrm{H}$ NMR, ${ }^{b}$ SPB unit number, ${ }^{c}$ Unit ratio of SPB and PEGMA, ${ }^{d}$ Lower glass transition temperature, ${ }^{e}$ Higher glass transition temperature.

\subsection{Thermal Properties}

DSC measurements were performed on the diblock copolymers in order to detemine the thermal properties. Figure 2 shows (a) DSC curves of neat diblock copolymers, PPEGMA $_{68}-b-\mathrm{SPB}_{\mathrm{m}}$, and (b) PPEGMA ${ }_{68}-b-\mathrm{SPB}_{121} / \mathrm{LiTFSA}$ composites at the 2nd heating scan. All the neat diblock copolymers exhibited two distinct glass transition temperature $\left(\mathrm{T}_{g}\right)$ values at around -75 and $5{ }^{\circ} \mathrm{C}$ as shown in Figure $2 \mathrm{a}$. The $\mathrm{T}_{\mathrm{g}}$ values are also summarized in Table 1 . The lower $\mathrm{T}_{\mathrm{g}}\left(\mathrm{T}_{\mathrm{g}, \mathrm{L}}\right)$ is almost the same with the $\mathrm{T}_{\mathrm{g}}\left(-74^{\circ} \mathrm{C}\right)$ of PPEGMA [29]. Galin et al. reported that a random copolymer composed of butyl acrylate and zwitterionic monomer exhibited two distinct $\mathrm{T}_{\mathrm{g}}$ values at -38 and $44{ }^{\circ} \mathrm{C}$, which corresponded to buryl acrylate and zwitterion, respectively [23]. The lower $\mathrm{T}_{\mathrm{g}}$ and higher $\mathrm{T}_{\mathrm{g}}$ should be based on PEGMA and SPB units, respectively. Both $T_{g, L}$ and $T_{g, H}$ exhibited almost the same values regardless of the unit ratio, $\mathrm{m} / \mathrm{n}$. These results indicate that PPEGMA and SPB are incompatible components and tend to spontaneously form phase-separated structures. AFM observation was performed to investigate phase-separated structures for PPEGMA $_{68}-b-\mathrm{SPB}_{\mathrm{m}}$. Microphase separation was observed for all the block coplymers (data not shown). The SPB block formed an aggregation in the matrix due to strong interaction between zwitterionic side-chains.

(a)

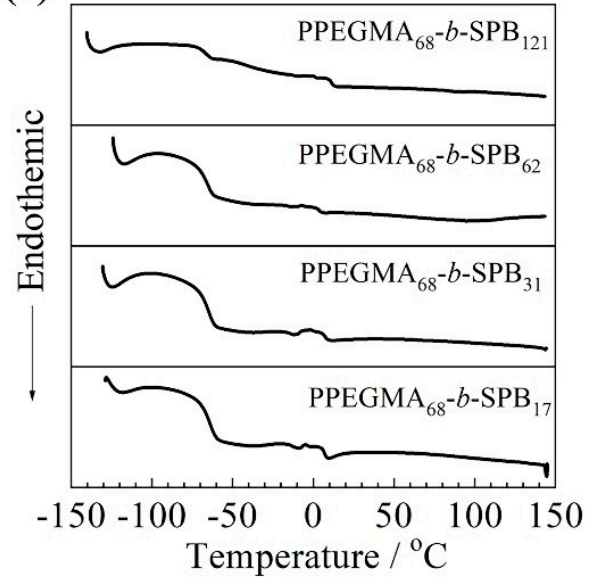

(b)

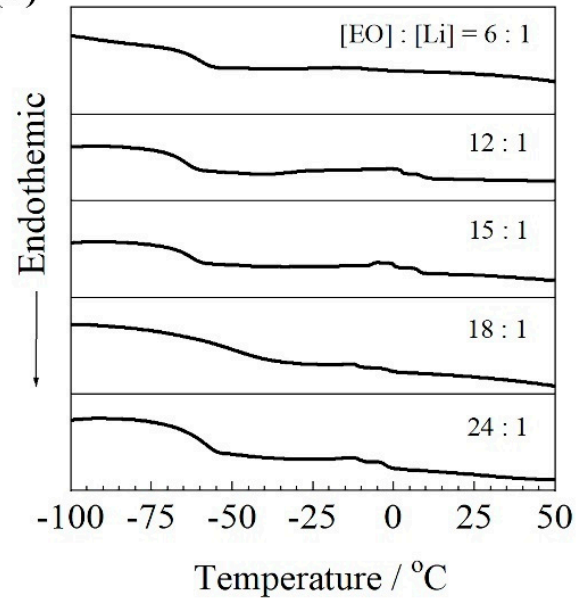

Figure 2. DSC traces of (a) PPEGMA $_{68}-b-\mathrm{SPB}_{\mathrm{m}}$ and (b) PPEGMA $\mathrm{P}_{68}-b-\mathrm{SPB}_{121} /$ LiTFSA composites (2nd heating).

PPEGMA $_{68}-b-\mathrm{SPB}_{121} /$ LiTFSA composites also exhibited two distinct $T_{\mathrm{g}}$ values at around -70 and $5{ }^{\circ} \mathrm{C}$ except for [EO]:[Li] $=6: 1$ as shown in Figure $2 \mathrm{~b}$. The $T_{\mathrm{g}, \mathrm{L}}$ values of PPEGMA $_{68}-$-b-SPB $_{121} /$ LiTFSA with [EO]:[Li] = 24:1, 18:1, 15:1, 12:1, and 6:1 were $-66,-65$, $-67,-69$, and $-67^{\circ} \mathrm{C}$, respectively. The $T_{\mathrm{g}, \mathrm{L}}$ of PPEGMA ${ }_{68}-b-\mathrm{SPB}_{121} /$ LiTFSA was about $10{ }^{\circ} \mathrm{C}$ higher than that of the neat block copolymer. This increase is assumed to be mainly based on the interaction between the ether oxygen of PEGMA units and $\mathrm{Li}^{+}$. Interestingly, the $T_{\mathrm{g}, \mathrm{L}}$ exhibited a constant value in the Li-salt concentration range of [EO]:[Li] $=24: 1$ and 6:1. The $T_{\mathrm{g}}$ of PEO-based electrolytes generally increases with increasing salt concentration due to the interaction (vide supra). On the other hand, the $T_{\mathrm{g}, \mathrm{H}}$ values of PPEGMA ${ }_{68^{-}}$ 
$b$-SPB 121 /LiTFSA with [EO]:[Li] $=24: 1,18: 1,15: 1$, and 12:1 were $-3,-2,7$, and $8{ }^{\circ} \mathrm{C}$, respectively. The $T_{\mathrm{g}, \mathrm{H}}$ of PPEGMA 68 - $b$-SPB $121 / \mathrm{LiTFSA}$ was lower than that of the neat block copolymer. A low molecular weight zwitterion, 4-(1-ethyl-1H-imidazol-3-ium-3yl)butane-1-sulfonate, exhibits a $T_{\mathrm{g}}$ at $18{ }^{\circ} \mathrm{C}$. Interestingly, the equimolar mixture of the zwitterion and LiTFSA forms a liquid at room temperature and exhibits a $T_{\mathrm{g}}$ at $-37^{\circ} \mathrm{C}$ [11]. The aggregation state of the SPB block will be plasticized by the addition of LiTFSA.

\subsection{Surface Morphology}

The surface morphology was investigated by AFM measurements for PPEGMA P8 $^{-} b-$ $\mathrm{SPB}_{121}$ with various LiTFSA concentrations ([EO]:[Li] = 6:1, 12:1, 18:1, and 24:1). Figure 3 shows AFM (a) height and (b) phase images of PPEGMA ${ }_{68}-b-\mathrm{SPB}_{121} /$ LiTFSA composites. Phase-separated structures were observed for both height and phase images of all the composites. In the AFM height images, round dark domains are the SPB block according to the volume ratio of SPB block and PEGMA block. The number of the round dark domains decreased with increasing LiTFSA concentration. In addition, the surface roughness decreased with increasing LiTFSA concentration. The AFM phase images also showed the same phase-separated structure as the height images. The aggregation of SPB block was observed as round bright domains in the phase images. The number of round bright domains decreased with increasing LiTFSA concentration. These results suggest that the SPB block was plasticized by the addition of LiTFSA, and the phase-separated structure was relaxed due to the mixture formation of SPB and PEGMA blocks. This tendency is in good accordance with the results of thermal properties.

(a)

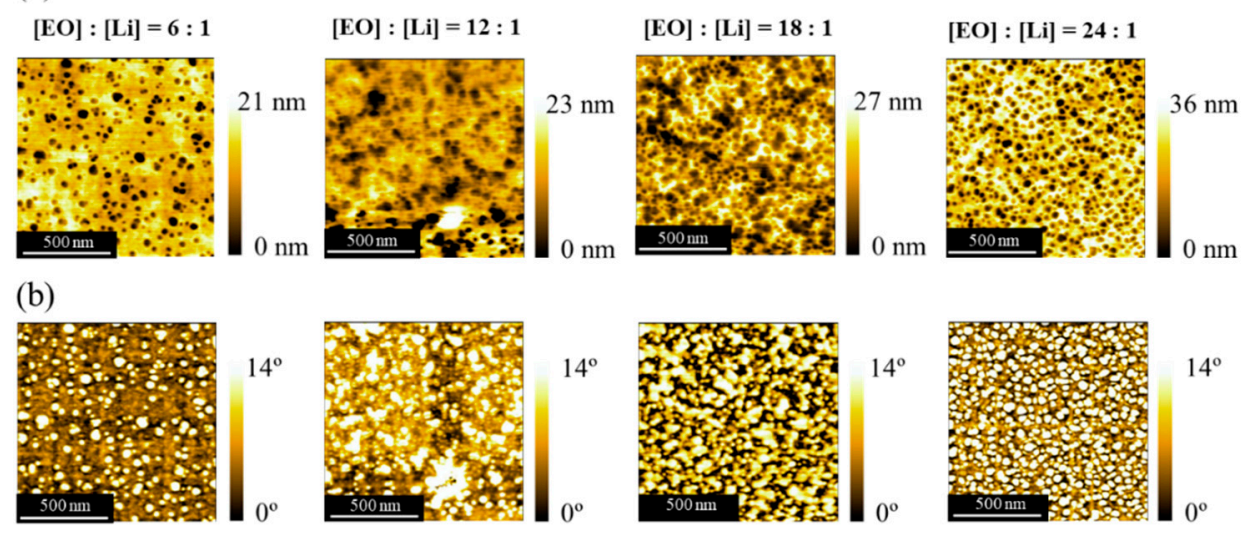

Figure 3. AFM (a) height and (b) phase images of PPEGMA $68^{-} b-\mathrm{SPB}_{121} / \mathrm{LiTFSA}$ composites.

\subsection{Ionic Conductivity}

The effect of the unit number of SPB on the ionic conductivity was investigated for PPEGMA ${ }_{68}-b-\mathrm{SPB}_{\mathrm{m}}(\mathrm{m}=17,31,62$, and 121). The Li-salt concentration was fixed at [EO]:[Li] = 6:1. Figure 4a shows the Arrhenius plots of ionic conductivities for PPEGMA 68 $b-\mathrm{SPB}_{\mathrm{m}} / \mathrm{LiTFSA}$ composites. The temperature dependence of ionic conductivities exhibited upper convex curves for all PPEGMA $68^{-} b-\mathrm{SPB}_{\mathrm{m}} / \mathrm{LiTFSA}$ composites, suggesting that the ion motion in the block copolymers is mainly coupled with the segmental motion of PPEGMA matrix, which is the typical ion conduction mechanism in a PEO matrix $[1,2]$. The ionic conductivities of PPEGMA $68_{6}-b-\mathrm{SPB}_{17}$ and PPEGMA ${ }_{68}-b-\mathrm{SPB}_{31}$ were almost the same within the temperature range measured in this study. The two block copolymers exhibited the highest ionic conductivity at higher temperatures above $60{ }^{\circ} \mathrm{C}$ in this study. On the other hand, at lower temperatures below $60^{\circ} \mathrm{C}$, the ionic conductivity of block copolymers increased with increasing the unit number of SPB. The ionic conductivity is governed by the number of carrier ions and carrier ion mobility. This tendency would result in the enhancement of Li-salt dissociation by SPB units, which has high polarity [22,23]. As a result, a large number of carrier ions is provided into the block copolymer matrix. Thus, 
PPEGMA $_{68}-b-\mathrm{SPB}_{121}$, which has a longer SPB block, exhibited higher ionic conductivity than those of the other block copolymers especially at lower temperature range below $60{ }^{\circ} \mathrm{C}$. In other words, PPEGMA ${ }_{68}-b-\mathrm{SPB}_{121}$ exhibited a gentle slope (lower activation energy) for the Arrhenius plot of ionic conductivity, suggesting that the polarity of the zwitterion structure prevents the aggregation of dissociated ions by the enhancement of Li-salt dissociation.
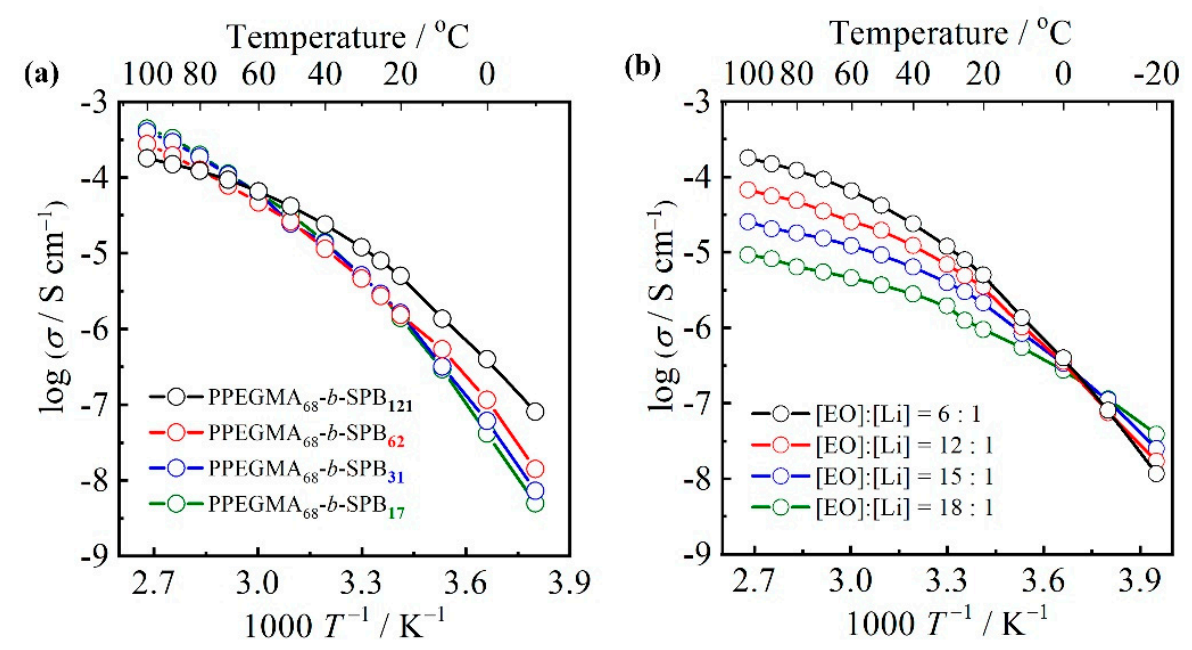

Figure 4. Arrhenius plots of ionic conductivities for (a) PPEGMA 68 - $b-\mathrm{SPB}_{\mathrm{m}} / \mathrm{LiTFSA}$ composites ([EO]:[Li] $=6: 1$ ) and (b) PPEGMA $_{68}-b-$ SPB $_{121} /$ LiTFSA composites.

The effect of the Li-salt concentration on the ionic conductivity was investigated for PPEGMA $_{68}-b-\mathrm{SPB}_{121} /$ LiTFSA composite, which exhibited the highest ionic conductivity of $10^{-5} \mathrm{~S} \mathrm{~cm}^{-1}$ at $25^{\circ} \mathrm{C}$ among the four block copolymers. Figure $4 \mathrm{~b}$ shows the Arrhenius plots of ionic conductivities for PPEGMA $68-b-\mathrm{SPB}_{121} /$ LiTFSA composites. The Li-salt concentration was changed in the range of $[\mathrm{EO}]:[\mathrm{Li}]=6: 1$ and $18: 1$. The ionic conductivity of PPEGMA $68-b-\mathrm{SPB}_{121} /$ LiTFSA composites increased with increasing Li-salt concentration from $[\mathrm{EO}]:[\mathrm{Li}]=18: 1$ to $6: 1$. In general, PEO-based electrolytes show the highest ionic conductivity at around [EO]:[Li] = 20:1 [3,30] because the introduction of a large amount of $\mathrm{Li}$-salt into the PEO matrix induces an increase in $\mathrm{T}_{\mathrm{g}}$, namely, the decrease in segmental motion of PEO matrix, which results in the decrease in ionic conductivity. PPEGMA ${ }_{68}$ $b$-SPB ${ }_{121} /$ LiTFSA composites exhibited an unusual tendency for Li-salt concentration dependence on ionic conductivity. This is attributed to the high polarity of the zwitterion structure in the SPB units enhancing the Li-salt dissociation (vide supra).

\subsection{Electrochemical Properties}

The electrochemical stability of electrolyte materials is an important factor in determining the battery performance. To determine the effect of the SPB block on the electrochemical stability of the diblock copolymers, linear sweep voltammetry (LSV) measurements were carried out at $60^{\circ} \mathrm{C}$. Figure 5a shows the LSV results of PPEGMA ${ }_{68} /$ LiTFSA and PPEGMA $_{68}-b-\mathrm{SPB}_{121} /$ LiTFSA (anodic scan from 2.9 to $5.6 \mathrm{~V}$ ). The oxidation potential of PPEGMA was approximately $4.2 \mathrm{~V}$ vs. $\mathrm{Li} / \mathrm{Li}^{+}$, which is identical to the value reported previously for PEO-based electrolytes [31]. On the other hand, the oxidation potential of PPEGMA ${ }_{68}^{-} b-\mathrm{SPB}_{121}$ was approximately $5.0 \mathrm{~V}$ vs. $\mathrm{Li} / \mathrm{Li}^{+}$. The oxidation limit was improved from 4.2 to $5.0 \mathrm{~V}$ by the introduction of SPB block in the copolymer. We have already reported that the oxidation limit of oligoether electrolytes is improved from around 4.5 to over $5.0 \mathrm{~V}$ vs. $\mathrm{Li} / \mathrm{Li}^{+}$by the addition of zwitterions [17,18]. The effect of zwitterion on the interfacial structures of $\mathrm{Pt} /$ tetraglyme (G4)-LiTFSA systems was investigated using in-situ infrared-visible sum frequency generation (IV-SFG) spectroscopy [32]. The SFG spectra confirmed that the Pt surface is covered by the $\mathrm{Li}^{+} /$zwitterion complex cations, which are more stable to oxidation than free G4 molecules. The enhancement of electro- 
chemical stability of PPEGMA $_{68}-\mathrm{b}_{-} \mathrm{SPB}_{121}$ is in good accordance with the results of G4 system, suggesting that the formation of $\mathrm{Li}^{+} / \mathrm{SPB}$ complex results in full coverage of the SPB block at the Pt electrode surface which accounts for the enhanced oxidation stability of the block copolymers.

(a)

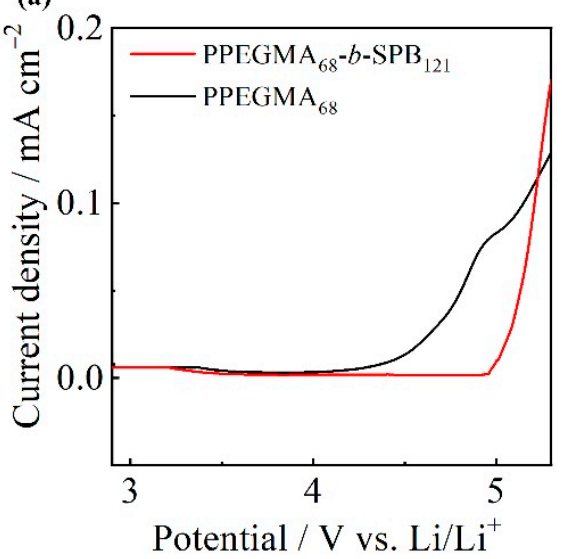

(b)

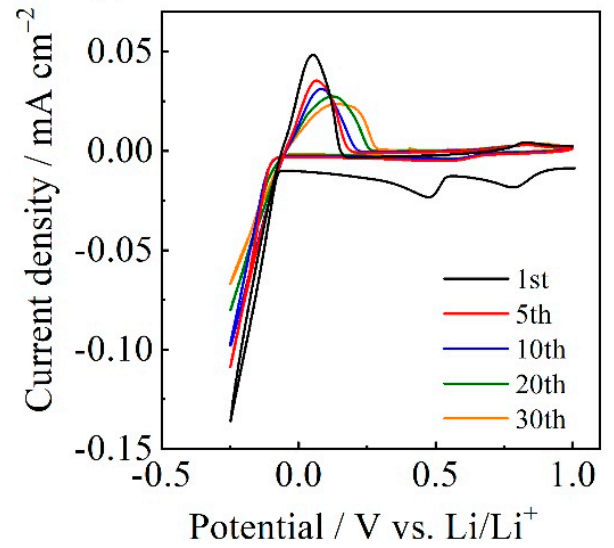

Figure 5. (a) Linear sweep voltammograms of PPEGMA 68 LiTFSA and PPEGMA $68^{-b}-$ $\mathrm{SPB}_{121} / \mathrm{LiTFSA}$ at $60^{\circ} \mathrm{C}$ (scan rate: $1 \mathrm{mV} \mathrm{s}^{-1}$; working electrode: $\mathrm{Pt}$; counter and reference electrodes: $\mathrm{Li}$ ), and (b) cyclic voltammograms of PPEGMA $68^{-} b-\mathrm{SPB}_{121} / \mathrm{LiTFSA}$ at $60^{\circ} \mathrm{C}$ (scan rate: $10 \mathrm{mV} \mathrm{s}^{-1}$; working electrode: $\mathrm{Ni}$; counter and reference electrode: $\mathrm{Li}$ ).

Figure $5 \mathrm{~b}$ shows the $\mathrm{CV}$ results of $\mathrm{PPEGMA}_{68}-b-\mathrm{SPB}_{121} / \mathrm{LiTFSA}$ composites on $\mathrm{Ni}$ electrodes at $60^{\circ} \mathrm{C}$. Continuous anodic current and two reduction peaks at 0.5 and $0.8 \mathrm{~V}$ vs. $\mathrm{Li} / \mathrm{Li}^{+}$were observed only at the 1 st anodic scan. These anodic current and reduction peaks will be associated with the reactions of oxides and water remaining on electrode suface [33]. The voltammograms of the composite electrolyte showed a reduction peak at $-0.2 \mathrm{~V}$ vs. $\mathrm{Li} / \mathrm{Li}^{+}$and an oxidation peak at $0.1 \mathrm{~V}$ vs. $\mathrm{Li} / \mathrm{Li}^{+}$for $\mathrm{Li}$ at the 1 st cycle. These reduction and oxidation peaks were observed over 30 cycles. However, the current density of the peaks decreased with increasing the number of cycles. In addition, the maximum current density of the oxidation peak shifted to a higher potential value and was broadened with an increasing number of cycles. These observations has been attributed to the formation of a suitable solid electrolyte interphase (SEI) film on the electrode surface [34]. The stable stripping/plating reactions were observed over 30 cycles, indicating that the block copolymers composed of PEGMA and SPB function as a Li-ion conductor.

\subsection{Charge/Discharge Properties}

Figure 6 shows (a) the discharge capacities and (b) coulombic efficiencies of the $\mathrm{Li} /$ electrolyte/NMC cells (electrolyte: $\left[\mathrm{C}_{3} \mathrm{mpyr}\right]$ [FSA]/LiFSA $\left.\left(0.32 \mathrm{~mol} \mathrm{~kg}^{-1}\right)\right)$ over $60 \mathrm{cy}-$ cles in the cut-off voltage range of 3.0-4.6 V. The cathode surface was coated by PPEGMA $68^{-}$ $b$-SPB 121 . Pristine cathode was also used for comparison. The discharge capacity of the cell employing the pristine cathode was $140 \mathrm{mAh} \mathrm{g}^{-1}$ during the first 10 cycles and gradually decreased with an increasing number of cycles. Finally, the cell exhibited no discharge capacity at the 50th cycle. The coulombic efficiency of the cell employing the pristine cathode exhibited the same tendency with the discharge capacity and was maintained at $95 \%$ during the first 10 cycles. The coulombic efficiency decreased with increasing cycle number and reached $0 \%$ at the 50th cycle. On the other hand, the discharge capacity of the cell employing the cathode coated with PPEGMA ${ }_{68}-b-\mathrm{SPB}_{121}$ exhibited a constant value of $145 \mathrm{mAh} \mathrm{g}^{-1}$ during the first 10 cycles and gradually decreased with increasing cycle number, from $145 \mathrm{mAh} \mathrm{g}^{-1}$ to $120 \mathrm{mAh} \mathrm{g}^{-1}$ at the 60th cycle. The coulombic efficiency of the cell employing the cathode coated with the block copolymer exceeded $90 \%$ over 60 cycles. The discharge capacity and coulombic efficiency of the cell employing the coated cathode were much higher than those of the cell employing the pristine cathode at the 50th 
cycle. The coating of PPEGMA ${ }_{68}-b-\mathrm{SPB}_{121}$ on the cathode surface was effective to lower the rate of cell capacity and coulombic efficiency fading in the cells at high cut-off voltage values. The effect of zwitterions on charge/discharge properties of $\mathrm{Li} /$ electrolyte $/ \mathrm{LiCoO}_{2}$ cells with oligoether and ionic liquid electrolytes has been reported in the same cut-off voltage range of 3.0-4.6 V [17,28,35]. Although the discharge capacities and coulombic efficiencies of the cells employing the electrolytes without zwitterions decreased with cycle number, the addition of zwitterions into the electrolytes was effective to stablilize the discharge capacities and coulombic efficiencies during 50 cycles. This should be based on the improvement of oxidation stability of electrolyte materials by the addition of zwitterions. In the cells employing the cathode coated by the block copolymers, the SPB block on the electrode surface also improves the oxidation stability of electrolyte materials at higher cut-off voltages. In general, the discharge capacity of cells employing cathode active materials such as NMC and LCO increases with increasing cut-off voltage value. This type of material, which prevents the decomposition of electrolyte materials at higher voltages, is intended for the development of deep discharge batteries and will open a new methodology to improve the charge/discharge properties of Li batteries.

(a)

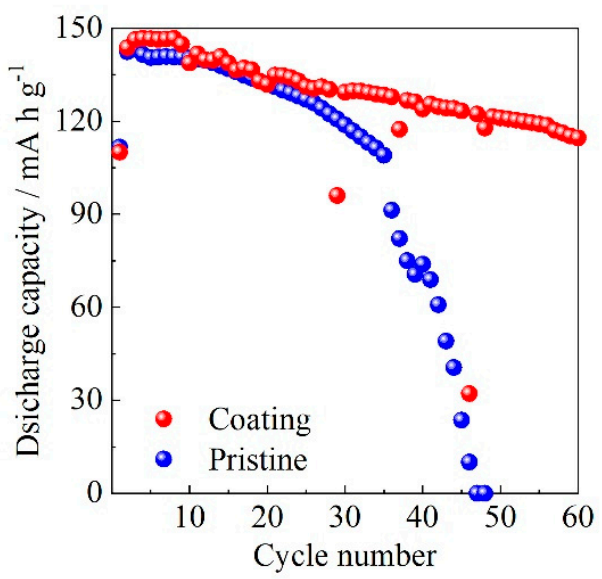

(b)

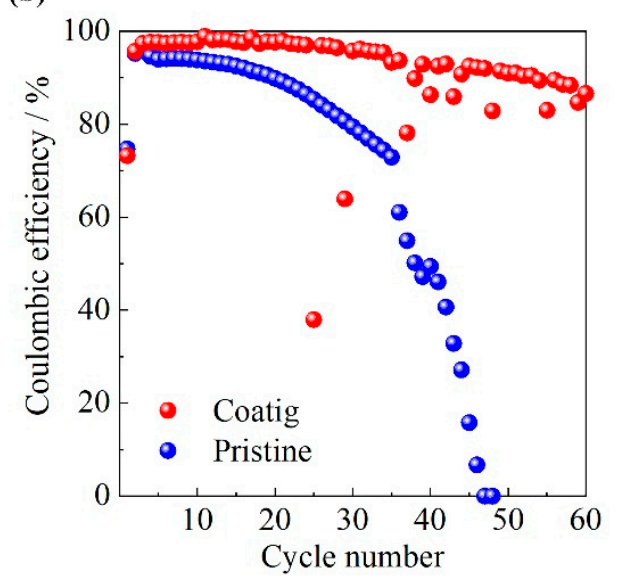

Figure 6. (a) Discharge capacities and (b) coulombic efficiencies of $\mathrm{Li} / \mathrm{NMC}$ cells containing $\left[\mathrm{C}_{3} \mathrm{mpyr}\right.$ ] [FSA] over 60 cycles in the cut-off voltage range of 3.0-4.6 V at $60^{\circ} \mathrm{C}$ (Charge/discharge rate: $0.5 \mathrm{C}$ ).

\section{Conclusions}

The block copolymers, PPEGMA $68-b-\mathrm{SPB}_{m}(m=17,31,62$, and 121), with wellcontrolled molecular weights were synthesized by RAFT polymerization. The $M_{n}$ of PPEGMA $_{68}-b-\mathrm{SPB}_{m}$ was determined by ${ }^{1} \mathrm{H}$ NMR measurements to be in the range of 37,800 and $67,000 \mathrm{~g} \mathrm{~mol}^{-1}$. All the neat diblock copolymers exhibited two distinct $T_{\mathrm{g}}$ values at around -75 and $5{ }^{\circ} \mathrm{C}$, which are associated with PEGMA and SPB units, respectively. PPEGMA $_{68}-b-\mathrm{SPB}_{m} /$ LiTFSA composites also exhibited two distinct $T_{\mathrm{g}} \mathrm{s}$ except for [EO]:[Li] $=6: 1$. PEGMA and SPB are incompatible components and tend to spontaneously form phase-separated structures. Microphase separation was observed for all the block copolymers and their LiTFSA composites in AFM observation. PPEGMA ${ }_{68}-b-\mathrm{SPB}_{121} / \mathrm{LiTFSA}$ composites exhibited higher ionic conductivities than those of the block copolymers with lower SPB contents. The ionic conductivity of PPEGMA ${ }_{68}-b-\mathrm{SPB}_{121} /$ LiTFSA composites increased with increasing LiTFSA concentration. These results would result in the enhancement of Li-salt dissociation by SPB units, which has high polarity. The oxidation potential of PPEGMA ${ }_{68}^{-b}-\mathrm{SPB}_{121}$ was approximately $5.0 \mathrm{~V} \mathrm{vs}$. $\mathrm{Li} / \mathrm{Li}^{+}$. The oxidation limit was improved by the introduction of the SPB block in the PEO-based copolymers. The stable stripping/plating reactions of $\mathrm{Li}$ were observed over 30 cycles in CV measurements. The block copolymers were composed of PEGMA, and SPB functions as a Li-ion conductor. The Li/NMC cells were fabricated by using an NMC surface coated with PPEGMA ${ }_{68}{ }^{-}$ $b-\mathrm{SPB}_{121}$. The discharge capacity and coulombic efficiency of the cells exhibited higher 
values at the 60th cycle as compared with those of the cells with pristine NMC in the cut-off voltage range of 3.0-4.6 V. The SPB block on the electrode surface improves the oxidation stability of electrolyte materials at higher cut-off voltages. Zwitterions function effectively as cathode-coating materials in Li batteries. This will be a new methodology to improve charge/discharge properties of not only Li batteries but also other rechargeable batteries.

Author Contributions: Conceptualization, M.Y.-F. and J.I.; methodology, M.Y.-F. and J.I.; software, M.Y.-F. and J.I.; validation, M.Y.-F., Y.T. and M.R.; formal analysis, J.I.; investigation, M.Y.-F., Y.T. and M.R.; resources, M.Y.-F.; data curation, M.Y.-F. and J.I.; writing-original draft preparation, M.Y.-F. and J.I.; writing-review and editing, M.Y.-F.; visualization, M.Y.-F.; supervision, M.Y.-F.; project administration, M.Y.-F.; funding acquisition, M.Y.-F. All authors have read and agreed to the published version of the manuscript.

Funding: This study was supported by a Grant-in-Aid for Scientific Research (C) (No. 26410140) from the Japan Society for the Promotion of Science (JSPS).

Institutional Review Board Statement: Not applicable.

Informed Consent Statement: Not applicable.

Data Availability Statement: The data presented in this study are available on request from the corresponding author.

Acknowledgments: We acknowledge support by the Japan Society for the Promotion of Science (JSPS).

Conflicts of Interest: The authors declare no conflict of interest.

\section{References}

1. Gray, F.M. Polymer Electrolyte; Royal Society of Chemistry: Cambridge, UK, 1997.

2. Meyer, W.H. Polymer Electrolytes for Lithium-Ion Batteries. Adv. Mater. 1998, 10, 439-448. [CrossRef]

3. Tominaga, Y.; Yamazaki, K. Fast Li-ion conduction in poly(ethylene carbonate)-based electrolytes and composites filled with $\mathrm{TiO}_{2}$ nanoparticles. Chem. Commun. 2014, 50, 4448-4450. [CrossRef]

4. Okumura, T.; Nishimura, S. Lithium ion conductive properties of aliphatic polycarbonate. Solid State Ionics 2014, 267, 68-73. [CrossRef]

5. Sun, B.; Mindemark, J.; Edström, K.; Brandell, D. Polycarbonate-based solid polymer electrolytes for Li-ion batteries. Solid State Ionics 2014, 262, 738-742. [CrossRef]

6. Mackanic, D.G.; Yan, X.; Zhang, Q.; Matsuhisa, N.; Yu, Z.; Jiang, Y.; Manika, T.; Lopez, J.; Yan, H.; Liu, K.; et al. Decoupling of mechanical properties and ionic conductivity in supramolecular lithium ion conductors. Nat. Commun. 2019, 10, 5384. [CrossRef]

7. Xue, Z.; He, D.; Xie, X. Poly(ethylene oxide)-based electrolytes for lithium-ion batteries. J. Mater. Chem. A 2015, 3, 19218-19253. [CrossRef]

8. Croce, F.; Appetecchi, G.B.; Persi, L.; Scrosati, B. Nanocomposite polymer electrolytes for lithium batteries. Nature 1998, 394, 456-458. [CrossRef]

9. Croce, F.; Curini, R.; Martinelli, A.; Persi, L.; Ronci, F.; Scrosati, B.; Caminiti, R. Physical and Chemical Properties of Nanocomposite Polymer Electrolytes. J. Phys. Chem. B 1999, 103, 10632-10638. [CrossRef]

10. Yoshizawa, M.; Hirao, M.; Ito-Akita, K.; Ohno, H. Ion conduction in zwitterionic-type molten salts and their polymers. J. Mater. Chem. 2001, 11, 1057-1062. [CrossRef]

11. Yoshizawa, M.; Narita, A.; Ohno, H. Design of Ionic Liquids for Electrochemical Applications. Aust. J. Chem. 2004, 57, 139-144. [CrossRef]

12. Ohno, H.; Yoshizawa-Fujita, M.; Kohno, Y. Design and properties of functional zwitterions derived from ionic liquids. Phys. Chem. Chem. Phys. 2018, 20, 10978-10991. [CrossRef] [PubMed]

13. Tiyapiboonchaiya, C.; Pringle, J.M.; Sun, J.; Byrne, N.; Howlett, P.C.; MacFarlane, D.R.; Forsyth, M. The zwitterion effect in high-conductivity polyelectrolyte materials. Nat. Mater. 2004, 3, 29-32. [CrossRef] [PubMed]

14. Byrne, N.; Pringle, J.M.; Tiyapiboonchaiya, C.; MacFarlane, D.R.; Forsyth, M. The additive effect of zwitterion and nano-particles on ion dissociation in polyelectrolytes. Electrochim. Acta 2005, 50, 2733-2738. [CrossRef]

15. Byrne, N.; Howlett, P.C.; MacFarlane, D.R.; Forsyth, M. The Zwitterion Effect in Ionic Liquids: Towards Practical Rechargeable Lithium-Metal Batteries. Adv. Mater. 2005, 17, 2497-2501. [CrossRef]

16. Yoshizawa-Fujita, M.; Tamura, T.; Takeoka, Y.; Rikukawa, M. Low-melting zwitterion: Effect of oxyethylene units on thermal properties and conductivity. Chem. Commun. 2011, 47, 2345-2347. [CrossRef]

17. Yamaguchi, S.; Yoshizawa-Fujita, M.; Zhu, H.; Forsyth, M.; Takeoka, Y.; Rikukawa, M. Improvement of charge/discharge properties of oligoether electrolytes by zwitterions with an attached cyano group for use in lithium-ion secondary batteries. Electrochim. Acta 2015, 186, 471-477. [CrossRef] 
18. Suematsu, M.; Yoshizawa-Fujita, M.; Zhu, H.; Forsyth, M.; Takeoka, Y.; Rikukawa, M. Effect of zwitterions on electrochemical properties of oligoether-based electrolytes. Electrochim. Acta 2015, 175, 209-213. [CrossRef]

19. Xu, K. Nonaqueous Liquid Electrolytes for Lithium-Based Rechargeable Batteries. Chem. Rev. 2004, 104, 4303-4418. [CrossRef]

20. Zhang, H.; Chen, F.; Lakuntza, O.; Oteo, U.; Qiao, L.; Martinez-Ibañez, M.; Zhu, H.; Carrasco, J.; Forsyth, M.; Armand, M. Suppressed Mobility of Negative Charges in Polymer Electrolytes with an Ether-Functionalized Anion. Angew. Chem. Int. Ed. 2019, 58, 12070-12075. [CrossRef]

21. Yoshizawa-Fujita, M.; Shimada, K.; Takeoka, Y.; Rikukawa, M. Synthesis of Random Copolymers Containing Zwitterions and Their Evaluation as Electrolyte Materials. Kobunshi Ronbunshu 2015, 72, 624-629. [CrossRef]

22. Galin, M.; Marchal, E.; Mathis, A.; Galin, J.-C. Poly(ammonioalkanesulfonate) Blends with Polar Organic Species and Alkali Metal Salts: Structure, Glass Transition and Ionic Conductivity. Polym. Adv. Technol. 1997, 8, 75-86. [CrossRef]

23. Galin, M.; Mathis, A.; Galin, J.-C. Amorphous blends of poly(zwitterions) and zwitterionomers of the ammonioalkoxydicyanoethenolate type with some alkali metal salts. Polym. Adv. Technol. 2001, 12, 574-582. [CrossRef]

24. Yue, L.; Ma, J.; Zhang, J.; Zhao, J.; Dong, S.; Liu, Z.; Cui, G.; Chen, L. All solid-state polymer electrolytes for high-performance lithium ion batteries. Energy Storage Mater. 2016, 5, 139-164. [CrossRef]

25. Niitani, T.; Shimada, M.; Kawamura, K.; Kanamura, K. Characteristics of new-type solid polymer electrolyte controlling nano-structure. J. Power Sources 2005, 146, 386-390. [CrossRef]

26. Niitani, T.; Shimada, M.; Kawamura, K.; Dokko, K.; Rho, Y.-H.; Kanamura, K. Synthesis of Li[sup +] Ion Conductive PEO-PSt Block Copolymer Electrolyte with Microphase Separation Structure. Electrochem. Solid-State Lett. 2005, 8, A385. [CrossRef]

27. Matsumoto, T.; Ichikawa, T.; Ohno, H. Design of ionic liquid-based polyelectrolytes by combining 'nanostructurisation' and 'zwitterionisation'. Polym. Chem. 2016, 7, 1230-1233. [CrossRef]

28. Yamaguchi, S.; Yoshizawa-Fujita, M.; Takeoka, Y.; Rikukawa, M. Effect of a pyrrolidinium zwitterion on charge/discharge cycle properties of $\mathrm{Li} / \mathrm{LiCoO}_{2}$ and graphite/Li cells containing an ionic liquid electrolyte. J. Power Sources 2016, 331, 308-314. [CrossRef]

29. Di Marco, G.; Lanza, M.; Pieruccini, M. Influence of poly(ethylene glycol)methacrylate on the morphology and conductivity of poly(ethylene oxide)-sodium thiocyanate complexes. Solid State Ionics 1996, 89, 117-125. [CrossRef]

30. Ratner, M.A.; Shriver, D.F. Ion transport in solvent-free polymers. Chem. Rev. 1988, 88, 109-124. [CrossRef]

31. Yang, X.; Jiang, M.; Gao, X.; Bao, D.; Sun, Q.; Holmes, N.; Duan, H.; Mukherjee, S.; Adair, K.; Zhao, C.; et al. Determining the limiting factor of the electrochemical stability window for PEO-based solid polymer electrolytes: Main chain or terminal -OH group? Energy Environ. Sci. 2020, 13, 1318-1325. [CrossRef]

32. Qi, C.; Iwahashi, T.; Zhou, W.; Kim, D.; Yamaguchi, S.; Yoshizawa-Fujita, M.; Ouchi, Y. Enhancement of the electrochemical stability of tetraglyme-Li[TFSA] electrolyte systems by adding [Bimps] zwitterion: An in-situ IV-SFG study. Electrochim. Acta 2020, 361, 137020. [CrossRef]

33. Abraham, K.M.; Jiang, Z.; Carroll, B. Highly Conductive PEO-like Polymer Electrolytes. Chem. Mater. 1997, 9, 1978-1988. [CrossRef]

34. Cheng, X.-B.; Zhang, R.; Zhao, C.-Z.; Wei, F.; Zhang, J.-G.; Zhang, Q. A Review of Solid Electrolyte Interphases on Lithium Metal Anode. Adv. Sci. 2016, 3, 1500213. [CrossRef] [PubMed]

35. Horiuchi, S.; Zhu, H.; Forsyth, M.; Takeoka, Y.; Rikukawa, M.; Yoshizawa-Fujita, M. Synthesis and evaluation of a novel pyrrolidinium-based zwitterionic additive with an ether side chain for ionic liquid electrolytes in high-voltage lithium-ion batteries. Electrochim. Acta 2017, 241, 272-280. [CrossRef] 